\title{
Optimization in Agrobacterium-mediated transformation of Anthurium andraeanum using GFP as a reporter
}

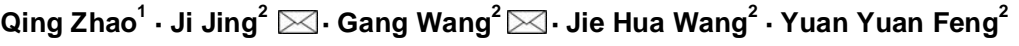 \\ Han Wen Xing ${ }^{2}$. Chun Feng Guan ${ }^{2}$ \\ 1 School of Chemical Engineering and Technology, Tianjin University, Tianjin 300072, PR China \\ 2 School of Agriculture and Bioengineering, Tianjin University, Tianjin 300072, PR China \\ $\triangle$ Corresponding author: jijing@tju.edu.cn - gangwang@tju.edu.cn \\ Received September 16, 2009 / Accepted May 5, 2010 \\ Published online: September 15, 2010 \\ (C) 2010 by Pontificia Universidad Católica de Valparaíso, Chile
}

\begin{abstract}
Although Agrobacterium-mediated transformation protocols for many economically important plant species have been well established, protocol for a number of flowering plants including Anthurium andraeanum remains challenging. In this study, we report success in generating transgenic Anthurium andraeanum cv Arizona using Agrobacterium GV3101 strain harboring a binary vector carrying gfp as a reporter gene. The possibility of facilitating the screening process for transgenic plants expressing functional proteins using gfp marker was explored. In order to realize high transformation efficiency, different explant sources including undifferentiated callus pieces and petioles were compared for their regeneration efficiency and susceptibility to Agrobacterium-mediated transformation. We also optimized the concentration of AS added to co-cultivation media. Genomic PCR revealed that 11 of the 22 resistant plantlets regenerated on selective medium were successfully transformed. Green fluorescence was observed using a fluorescence microscope in 7 of the 11 PCR-positive plants, indicating GFP was expressed stably in the transformed Anthurium andraeanum. The highest transformation efficiency obtained in this study was $1.71 \%$ (percentage of explants with transgenic shoots in total explants) when callus explants were used as starting material and $125 \mu \mathrm{mol} \mathrm{I}^{-1}$ AS was added during the co-cultivation process.
\end{abstract}

Keywords: cocultivation, gene transfer, green fluorescent protein, regeneration

\section{INTRODUCTION}

Anthurium, a member of the family Araceae (monocotyledon), is found in tropical America and is highly prized as an ornamental plant with its beautiful flowers and exotic foliage (Dufour and Guerin, 2003). It is economically desirable to breed new cultivars of Anthurium andraeanum and the most common breeding method is sexual hybridization. Genetic engineering can be used to introduce heterogenous genes that are not present in the gene pool of host plant, thus allowing novel phenotypes to be 
generated. Among the numerous methods for plant transformation, the Agrobacterium-mediated method is preferable because it generates a high proportion of independent transformants with single or low transgene copy numbers, which is usually favourable for expression of foreign genes (Dai et al. 2001; Shou et al. 2004).

In the past decades, tissue and organ culture systems for Anthurium andraeanum have been successfully established and plantlets were regenerated from both calli and somatic embryos. These methods facilitated the establishment of genetic transformation system of Anthurium andraeanum (Kuehnle et al. 1992; Vargas et al. 2004; Beyramizade et al. 2008; Yu et al. 2009). Success in Anthurium transformation was firstly reported in 1996 (Chen and Kuehnle, 1996), in which study the etiolated internode segments of Anthurium were co-cultured with Agrobacterium tumefaciens LBA4404 carrying chimeric genes. Root explants from several Anthurium cultivars were used for transformation research and their transformation efficiency was evaluated (Chen et al. 1997). Since then, Agrobacterium-mediated genetic transformation of Anthurium has been reported by several groups (Fitch et al. 2005; Fitch et al. 2006; Khaithong et al. 2006; Khaithong et al. 2007). However, literatures on Anthurium transformation are limited, and the transformation efficiency was fairly low. Therefore, it is desirable to optimize a transformation protocol with higher efficiency and easier selection method for Anthurium based on previously published methods.

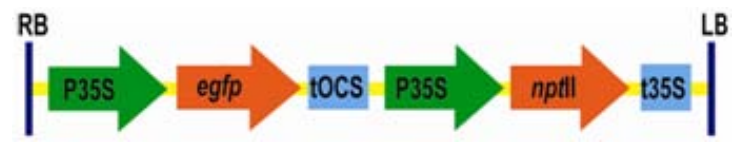

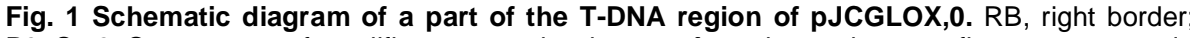
P35S, 35S promoter of cauliflower mosaic virus; egfp, enhanced green fluorescent protein reporter gene; tOCS, octopine synthase terminator; nptll, gene for neomycin phosphotransferase; t35S, terminator of cauliflower mosaic virus; LB, left border.

Green fluorescent protein (gfp) gene from the jellyfish (Aequiorea victoria), as a reporter gene, has been successfully applied to visual selection of transformed plants (Stewart, 2005). Transformation efficiency of a specific plant can be evaluated conveniently with the gfp gene as a result of a simple assay using a fluorescence microscope. We therefore utilized a binary vector pJCGLOX,0 (Joubès, 2004) that contains a modified gfp gene (egfp) as a reporter and neomycin phosphotransferase II (nptll) as a selectable marker to develop a transformation protocol for Anthurium andraeanum. The effects of explant sources and AS concentrations on transgenic Anthurium andraeanum yield are also discussed.

\section{MATERIALS AND METHODS}

\section{Plant materials and explants}

The explant materials for axenic tissue culture were surface-sterilized petioles previously described (Yao et al. 2006). Callus clumps with adventitious shoots were maintained in $1 / 2 \mathrm{MS}$ media containing $1.0 \mathrm{mg} \mathrm{l}^{-1}$ 6-BA and $0.1 \mathrm{mg} \mathrm{l}^{-1}$ 2,4-D under 
greenhouse conditions (natural photoperiod extended to $16 \mathrm{hrs}$ as required by giving a photon flux density of 5000 lux, temperature of $25^{\circ} \mathrm{C}$ ). Minced calli and petioles cut from these shoots were used for the following transformation procedure.

\section{Optimization of regeneration media and kanamycin sensitivity of explants}

To establish an efficient regeneration system, 1/2 MS media with different 6-BA concentrations $\left(0.3,0.5,0.7,1.0,1.3,1.5,2.0 \mathrm{mg} \mathrm{l}^{-1}\right)$ were used to test its efficacy in inducing shoots while the concentration of 2,4-D was kept constant at $0.1 \mathrm{mg} \mathrm{l}^{-1}$. The callus was cut into pieces $\left(0.5 \mathrm{~cm}^{3}\right)$ with all the adventitious shoots on the surface removed. About 35-40 minced callus explants were included in each treatment which was triplicated. Two months later, the morphogenetic characteristics of these explants were recorded and the numbers of adventitious shoots were counted.

To test the effects of kanamycin on Anthurium andraeanum, minced calli and petioles (32-65) were cultured in callus inducing medium (CIM) (Table 1) supplemented with kanamycin at different concentrations $\left(0,50,75,100,125,150 \mathrm{mg} \mathrm{l}^{-1}\right)$. Each treatment was repeated 3 times. After 4 weeks, the explants were transferred onto the same medium. After another four weeks, new calli and adventitious shoots were counted and recovery rate (proportion of explants callusing) was determined.

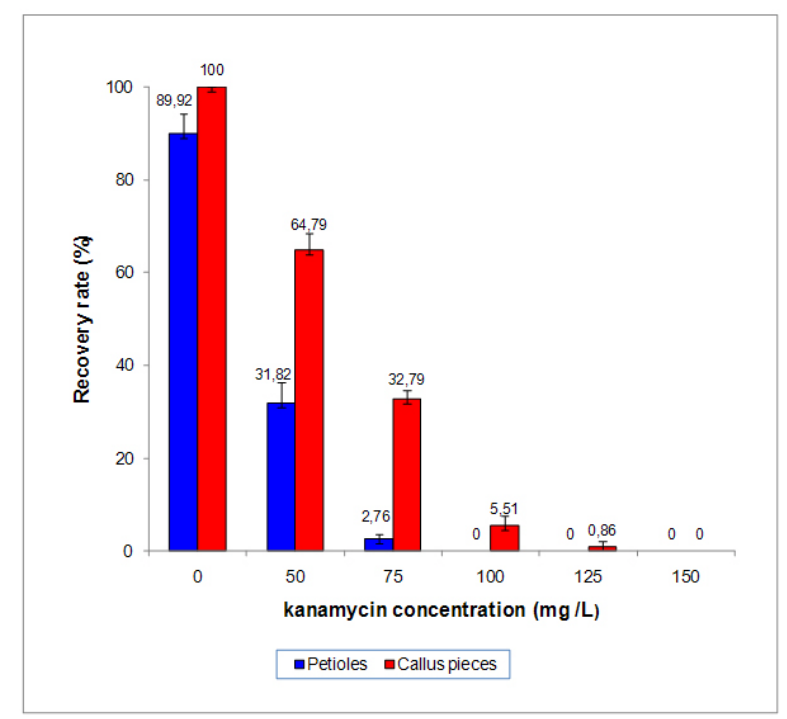

Fig. 2 Callus induction rate decrease with increasing concentrations of kanamycin. Error bars represent one standard error $(n=3)$.

\section{Agrobacterium strains and plasmid}

Agrobacterium tumefaciens strain GV3101 (pMP90RK) was used as the T-DNA donor (Koncz and Schell, 1986). Both gfp and nptll genes were driven by CaMV 35S promoters in plasmids pJCGLOX,0 (Figure 1) (Joubès, 2004). 


\section{Transformation and regeneration}

The Agrobacterium cells carrying the binary vector pJCGLOX,0 were grown in YEP liquid medium supplemented with $25 \mathrm{mg} \mathrm{ml}^{-1}$ chloromycin and $50 \mathrm{mg} \mathrm{ml}^{-1}$ gentamicin in a rotating $(200 \mathrm{rpm})$ incubator at $28^{\circ} \mathrm{C}$ for about $24 \mathrm{hrs}$. When the $\mathrm{OD}_{600}$ value reached 0.6-0.8, the cultures were centrifuged for $10 \mathrm{~min}$ at $4000 \mathrm{~g}$ and the bacterial pellet was re-suspended in liquid CCM (Table 1). Explants from callus pieces (40-63) and petioles (52-101) were then submerged in the inoculum for $30 \mathrm{~min}$, then transferred to solid CCM containing acetosyringone at different concentrations $(0,50$, $\left.75,100,125 \mu \mathrm{mol} \mathrm{I}^{-1}\right)$. Each treatment was repeated 3 times. After incubation for 3 days in the dark, the explants were washed twice in sterile $\mathrm{ddH}_{2} \mathrm{O}$ with $500 \mathrm{mg} \mathrm{m}^{-1}$ cefotaxime and placed on RM (Table 1) for 5 days in light. The explants were transferred to CIM-CK (Table 1) containing $400 \mathrm{mg} \mathrm{I}^{-1}$ and 125 or $100 \mathrm{mg} \mathrm{l}^{-1}$ kanamycin for calli and petioles, respectively. The explants were transferred to fresh CIM-CK every 3 weeks.

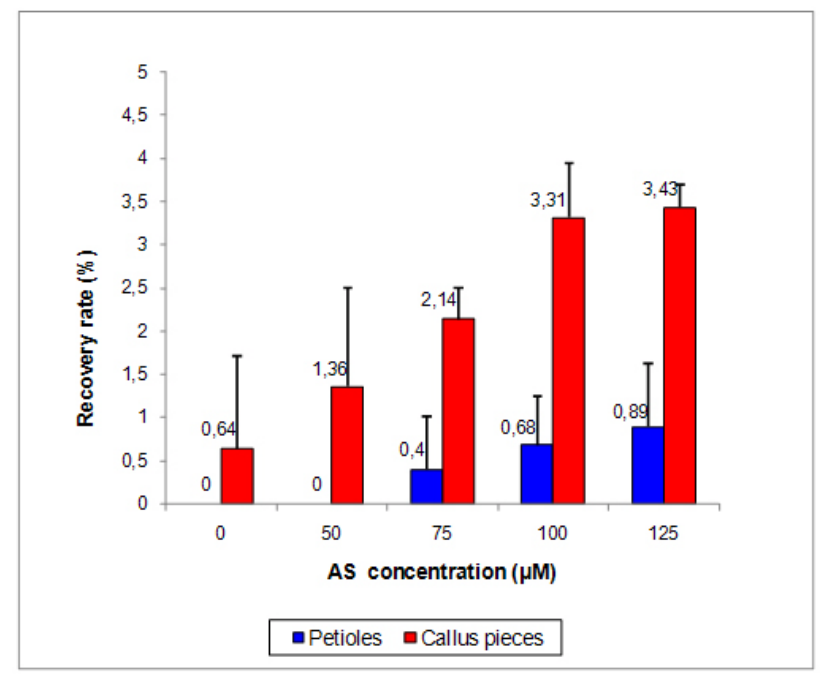

Fig. 3 Recovery rate of both explant sources rise with increasing AS concentration. Error bars represent standard error $(n=3)$.

Six months later, some rounded, green-yellow and newly formed calli appeared from the wounded callus pieces and petioles while other explants became yellow, dark and gradually died. The number of putative transformants was recorded for each treatment according to their explant source and AS concentration applied. Recovery rate (proportion of explants callusing on selective medium) was calculated accordingly. Resistant calli were transferred to shoot inducing medium (SIM) for shoot induction and regenerated shoots were rooted in root inducing medium (RIM) (Table $1)$.

Data regarding differentiation, recovery rate and transformation efficiency were analyzed with ANOVA; mean comparisons were made using Duncan's test $(P<0.05)$. 
Optimization in Agrobacterium-mediated transformation of Anthurium andraeanum using GFP as a reporter

\section{DNA isolation and genomic PCR analysis}

Genomic DNA was isolated from putative transformants and wild type plants using the CTAB method (Chaudhry et al. 1999). The DNA was tested by gfp primer pairs: 5'ACGTAAACGGCCACAAGTTC-3' and 5'-TAGCTCAGGTAGTGGTTGTCG-3'. PCR products were electrophoresed in agarose gel, stained with ethidium bromide and visualized under ultraviolet light (Sambrook and Russell, 2001).

\section{Visualization of GFP expression}

The expression of GFP was observed in callus tissue and regenerated plants under a fluorescent microscope (Olympus BX51, Japan) equipped with a fluorescence module consisting of a 100-W mercury lamp and GFP Plus excitation and emission filters. This system (excitation filter 480/40 nm; dichroic mirror $505 \mathrm{~nm} \mathrm{LP}$; barrier filter 510 $\mathrm{nm}$ LP) permits visualization of GFP following excitation by blue light.

\section{RESULTS AND DISCUSSION}

\section{Media for callus induction and shoot regeneration}

That callus or somatic embryo can be induced in vitro on explants by incorporation of plant hormones into a growth medium has been well established (Kuehnle et al. 1992; Vargas et al. 2004). For many plants, regeneration of transgenic shoots from callus is the bottleneck for genetic engineering. This is especially true when the callus originated from a few transformed cells with different regeneration requirements on selective media (Miguel and Oliveira, 1999). Cytokinin plays an important role in this response, therefore it was necessary to test the function of 6-BA in Anthurium regeneration.

Table 1. Media composition.

\begin{tabular}{|c|c|}
\hline Medium & Composition \\
\hline $\begin{array}{l}\text { CIM (callus inducing } \\
\text { medium) }\end{array}$ & 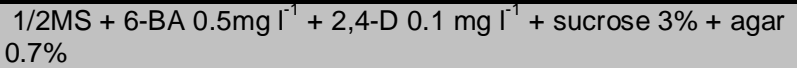 \\
\hline $\begin{array}{l}\text { CCM (co-cultivation } \\
\text { medium) }\end{array}$ & $\begin{array}{l}\text { 1/2MS + 6-BA } 0.5 \mathrm{mg} \mathrm{I}^{-1}+2,4-\mathrm{D} 0.1 \mathrm{mg} \mathrm{I}^{-1}+\text { sucrose } 3 \%+\text { agar } \\
0.7 \% \\
+\mathrm{AS}(0-125) \mu \mathrm{mol} \mathrm{I}^{-1}\end{array}$ \\
\hline $\begin{array}{l}\text { RM (recovery } \\
\text { medium) }\end{array}$ & 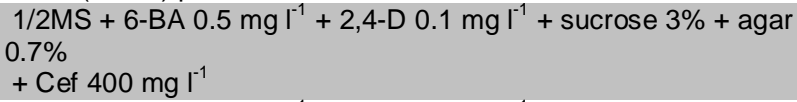 \\
\hline CIM-CK & $\begin{array}{l}\text { 1/2MS + 6-BA } 0.5 \mathrm{mg} \mathrm{l}^{-1}+2,4-\mathrm{D} 0.1 \mathrm{mg} \mathrm{l}^{-1}+\text { sucrose } 3 \%+\text { agar } \\
0.7 \% \\
+ \text { Cef } 400 \mathrm{mg} \mathrm{l}^{-1}+\operatorname{kan}(100 / 125) \mathrm{mg} \mathrm{l}^{-1}\end{array}$ \\
\hline $\begin{array}{l}\text { SIM (shoot inducing } \\
\text { medium) }\end{array}$ & $\begin{array}{l}\text { 1/2MS + 6-BA } 1.0 \mathrm{mg} \mathrm{I}^{-1}+2,4-\mathrm{D} 0.1 \mathrm{mg} \mathrm{I}^{-1}+\text { sucrose } 3 \%+\text { agar } \\
0.7 \% \\
+ \text { Cef } 400 \mathrm{mg} \mathrm{l}^{-1}+\mathrm{kan}^{(100 / 125) \mathrm{mg} \mathrm{l}^{-1}}\end{array}$ \\
\hline $\begin{array}{l}\text { RIM (root inducing } \\
\text { medium) }\end{array}$ & $\begin{array}{l}\text { 1/2MS }+2,4-\mathrm{D} 0.5 \mathrm{mg} \mathrm{l}^{-1}+\text { sucrose } 3 \%+\text { agar } 0.7 \%+\text { Cef } 400 \\
\mathrm{mg} \mathrm{l}^{-1}\end{array}$ \\
\hline
\end{tabular}


Based on our previous study, we maintained 2,4-D at $0.1 \mathrm{mg} \mathrm{I}^{-1}$ and changed the ratio of cytokinin to auxin by adjusting the concentration of 6-BA. Calli can be observed about 4 weeks after initiation of the cultures, however there were great differences in the morphogenetic response among the treatments (Table 2). Soft, quickly growing, pale or green yellow calli appeared in media with a lower 6-BA concentration ( 0.3 and $0.5 \mathrm{mg} \mathrm{l}^{-1}$ ). By the end of 8 weeks, these calli were larger than others and this could have result from quickly dividing cells. However, no shoots were generated. With increasing concentrations of 6-BA, shoots were induced on these explants while the growth rate of calli decreased gradually. When the 6-BA concentration was $2.0 \mathrm{mg} \mathrm{I}^{-1}$, callus formation was totally inhibited and no shoots appeared by the end of 8 weeks.

This study indicated that a lower ratio of cytokinin to auxin led to rapid division of the cells on the explant wounds, but these calli were not always regenerable. Although a higher 6-BA concentration resulted in slower cell proliferation, it resulted in shoot regeneration. Shoots were induced on the calli in media when the ratio of cytokinin to auxin was around 10. However, an even higher 6-BA was not beneficial for regeneration, instead it appeared to suppress cell division and inhibit shoot formation.

Based on above experiment, we chose $0.5 \mathrm{mg} \mathrm{l}^{-1}$ 6-BA with $0.1 \mathrm{mg} \mathrm{l}^{-1}$ 2,4-D for the callus inducing medium and $1.0 \mathrm{mg} \mathrm{l}^{-1} 6$-BA with $0.1 \mathrm{mg} \mathrm{l}^{-1} 2,4-\mathrm{D}$ for the shoot inducing medium for transformation.

\section{Kanamycin sensitivity}

Elucidating the effects of kanamycin at various concentrations on the growth of Anthurium andraeanum is a preliminary task for transformation research. When nontransformed explants from petioles and calli were maintained on CIM medium without kanamycin, $100 \%$ of the calli pieces and $89.92 \%$ of petioles produced new calli on the wounds, respectively. With increasing concentrations of kanamycin, both percentages decreased dramatically (Figure 2). No callus growth or shoot regeneration occurred in the medium containing $125 \mathrm{mg} \mathrm{l}^{-1}$ and $100 \mathrm{mg} \mathrm{l}^{-1}$ kanamycin or higher for explants from callus clumps and petioles, respectively. Therefore, selection by kanamycin at 125 and $100 \mathrm{mg} \mathrm{l}^{-1}$ was used for selecting transformants from callus and petiole tissues, respectively.
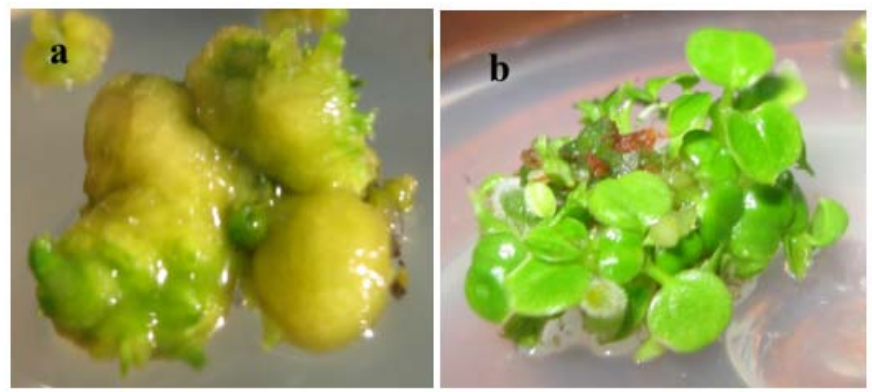

Fig. 4 Calli formation and shoots regeneration during selection step. (a) Transformed callus selected 6 months after co-cultivation of primary explants.

(b) Shoots were regenerated on the transformed callus. 


\section{Effect of AS and explant sources on transformation}

The transfer of T-DNA is mediated by the virulence genes in Agrobacterium. Transcription of these genes is induced by various phenolic compounds released by wounded plant cells. Induction of vir genes can also be achieved in vitro by cocultivation of Agrobacterium with wounded plant cells or tissues in media containing signal molecules such as AS (Stachel et al. 1986). AS has been commonly utilized in most transformation research for both dicotyledon and monocotyledon plants to enhance transformation efficiency (Frame et al. 2002; Olhoft et al. 2003; Kant et al. 2007). However, the effects of AS on Agrobacterium-mediated transformation is known to vary according to the plant species. There is even evidence to suggest that AS may suppress virulence in some strain/plant species interactions (Godwin et al. 1991). It was unclear whether or not AS enhanced transformation of Anthurium andraeanum. Elucidating the effects of AS on Anthurium transformation was an indispensable step to obtaining an optimal protocol.

Table 2. Morphogenic response of explants.

\begin{tabular}{cccc}
\hline \multicolumn{2}{c}{ Hormone composition } & \multicolumn{2}{c}{ Morphogenic response } \\
\hline $6-B A$ & $2,4-\mathrm{D}$ & Callus description & $\begin{array}{c}\text { Average } \\
\text { \#Shoots/Callus }\end{array}$ \\
$0.3 \mathrm{mg} / \mathrm{L}$ & $0.1 \mathrm{mg} / \mathrm{L}$ & Pale yellow, soft, quickly growing & $0 \mathrm{~d}^{*}$ \\
$0.5 \mathrm{mg} / \mathrm{L}$ & & Yellow green, soft, quickly growing & $0 \mathrm{~d}$ \\
$0.7 \mathrm{mg} / \mathrm{L}$ & & Yellow green, quickly growing & $2.00 \mathrm{ab}$ \\
$1.0 \mathrm{mg} / \mathrm{L}$ & Yellow green, moderately growing & $2.08 \mathrm{a}$ \\
$1.3 \mathrm{mg} / \mathrm{L}$ & & Green, hard, slowly growing & $1.78 \mathrm{bc}$ \\
$1.5 \mathrm{mg} / \mathrm{L}$ & Dark green, slowly growing & $1.75 \mathrm{c}$ \\
$2.0 \mathrm{mg} / \mathrm{L}$ & & Difficult to form callus on the wound & $0 \mathrm{~d}$ \\
\hline
\end{tabular}

*Different letters in the same column indicate significant differences, $5 \%$ level, Duncan's multiple range test.

For petiole explants, no resistant callus was generated with AS lower than $75 \mu \mathrm{mol} \mathrm{^{-1 }}$ in the co-cultivation media (Figure 3). The recovery rates increased with higher AS concentrations which reached $0.89 \%$ when the AS concentration was $125 \mu \mathrm{mol} \mathrm{I}{ }^{-1}$. On the other hand, callus-derived explants tended to produce a higher proportion of kanamycin resistant calli than those from petioles at the same AS concentration. The recovery rate was $0.64 \%$ even on AS-free co-cultivation media and increased to $3.43 \%$ in co-cultivation media with $125 \mathrm{mmol} \mathrm{I}^{-1} \mathrm{AS}$. The data demonstrated that AS enhanced the interaction between GV3101 and Anthurium cells, with the optimal AS dose used in this study was $125 \mu \mathrm{mol} \mathrm{I}{ }^{-1}$. Meanwhile, callus explants appear to be more suitable than petiole explants for transformation. This could be the result of differences in the morphogenetic competence and differential sensitivity of cells in different tissues (Yildiz et al. 2002; Jabeen et al. 2005; Nuñez et al. 2007).

\section{Selection strategy and transformant regeneration}

T-DNA transfer between Agrobacterium and the host plant is achieved during the cocultivation period and the plant cells become transformed. The length of the co- 
cultivation period depends on the plant species and explants involved. In this research, three days was chosen for the co-cultivation period, because this length produced the most kanamycin-resistant calli in our previous study. After co-cultivation, the explants were transferred to media without selective stress to allow for recovery from the agro-inoculation. This step is indispensable for Anthurium andraeanum transformation. No resistant callus was obtained without this step. The recovery step allows some time for the selective gene to express and accumulate to sufficient levels for transformants to grow in the selective media (Xu et al. 2009).

About two months later, some small, green yellow spots appeared on the wounded callus pieces and bases of petioles, while other explants became chlorotic and blackened. The new calli were cut from the original explants and inoculated to new CIM. Six months after co-cultivation, five putative transformants from petiole explants and seventeen from calli were obtained. When the resistant calli reached a suitable size (about $2 \mathrm{~cm}^{3}$ ) in CIM, they were transferred to SIM to induce shoot formation for a period of 6 to 8 months (Figure 4). Regenerated shoots were rooted in RIM.

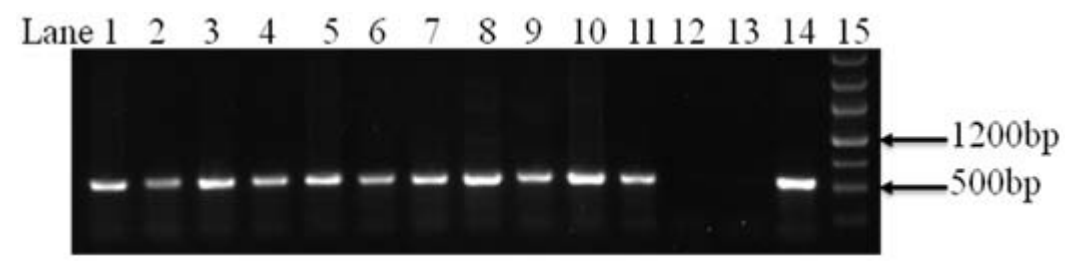

Fig. 5 Electrophoresis of PCR products. Lane 1-11, transformed plants, PCR products of expected size (547 bp) corresponding to egfp were amplified; Lane 12, wild type plant; Lane 13 , plant transformed with an empty vector (pJCGLOX,0 without gfp); Lane 14, vector pJCGLOX,0 as a positive control, corresponding product was amplified. Lane 15, Marker.

\section{PCR analysis and GFP detection}

After selection for 6 months with kanamycin, the presence or absence of gfp in all putative transformants was determined by genomic PCR analysis. PCR products of the expected size (547 bp) corresponding to egfp were amplified from 11 of the 22 kanamycin- resistant plants, whereas DNA from wild type plants and plants transformed with an empty vector (a same vector without gfp) did not yield such a product (Figure 5). All 5 plants from petiole explants were PCR positive, while only 6 of the 17 plants from callus were PCR positive. Statistical analysis reveals that both explant source and AS concentration affect transformation efficiency.

Transient expression was detected in explants about 2 days after co-cultivation, but the fluorescence disappeared in most materials in the following course. Stable expression of GFP in regenerated plants was observed with a fluorescence microscope. Despite the presence of the egfp gene in 11 transgenic lines, only 7 of the lines expressed GFP in young calli and stems (Figure 6). No GFP activity was detected in tissues from wild type plants and plants transformed with an empty vector, indicating that the green fluorescent areas were specific to GFP. The lack of protein expression is probably the result of gene inactivation. DNA methylation of the promoter region or some kind of gene silencing as a consequence of multiple insertions could be involved (Paszkowski and Whitham, 2001). Out of a total of 22 
regenerated plants, 11 (50\%) plants were PCR-positive and GFP was expressed in 7 $(63.64 \%)$ of these transformants. It is noteworthy that about $40 \%$ of plants shown to possess transgenes by PCR, did not express functional proteins. Therefore, GFP can be valuable to facilitate the screening process for transgenic plants that express functional proteins, if they are fused to the target gene. This may be important especially when kanamycin $(\mathrm{Km})$ is used for selection since it was recently shown that the proportion of "escapes" may be very high under Km-selection (Kuvshinov et al. 1999).

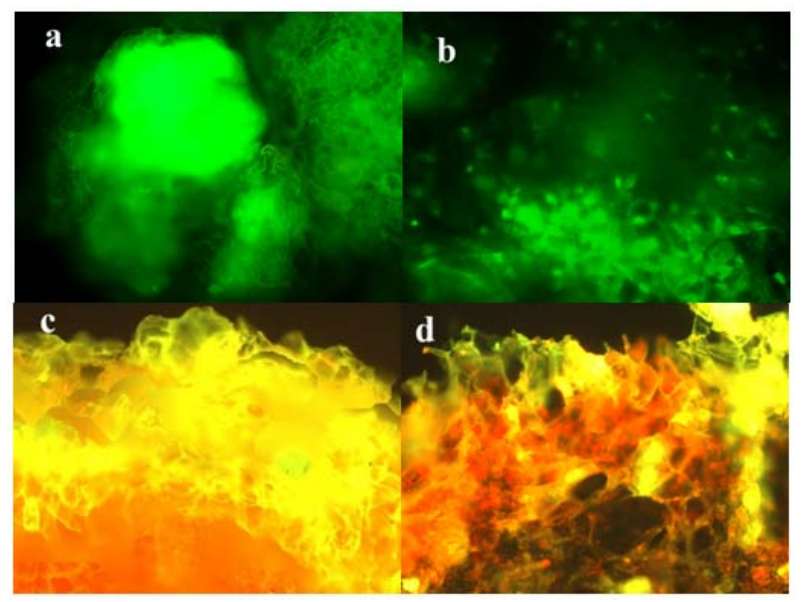

Fig. 6 Stable expression of eGFP in transformed callus (a) and stem cells (b), no green fluorescence was observed in wild type callus (c) and (d) callus transformed with empty vector ( $p J C G L O X, 0$ without gfp).

The gusA gene is another widely used reporter to detect transformed plants and cells. However, the assay for GUS activity requires histochemical staining with exogenous substrate and is destructive to plant tissues. The GFP gene has substantial advantages over other reporter and selectable genes for it is suitable for monitoring the time course of gene expression in living cells or for rapid screening of primary transformants (El-Shemy et al. 2004). Successful expression of GFP in Anthurium proved the feasibility of utilizing this novel gene in its transformation research.

As a monocot, Anthurium is not very susceptible to Agrobacterium-mediated transformation. Transformation efficiency is fairly low and cultivar-dependent, methods should be contrived to circumvent the problem. Chen and his colleagues got transformation efficiency of $1.3 \%$ (Chen et al. 1997). Since then, little work was reported about improvement of the data. The optimal transformation efficiency in this study was $1.71 \%$ using callus explants as starting material and $125 \mu \mathrm{mol} \mathrm{I}^{-1}$ AS during the co-cultivation process, which is significantly different from other treatments.

The production of transgenic plants is fundamental to investigations of gene function as well as to the improvement of horticultural traits in economically important flowers. Agrobacterium tumefaciens-mediated plant transformation has been used to generate transformants for both purposes. In the present study, we report an efficient protocol 
for shoot regeneration and Agrobacterium tumefaciens-mediated transformation from callus and petiole explants of Anthurium andraeanum. Agrobacterium-mediated transformation of Anthurium andraeanum was confirmed by PCR analysis and fluorescence microscopy. To date, we have not observed any phenotypic alterations in the transformed plants as a result of transformation. The development of transformation protocols will make it possible to engineer new traits into this promising ornamental species.

Financial support: The research was supported by Transgenic Anthurium Flowers, Butterfly Orchid Breeding Techniques and Rapid Propagation Technology of the Tianjin Science and Technology Commission (Grant no. 06YFGZNC01700) and National GMO Major Projects (Grant no. 2009ZX08003-019B).

\section{REFERENCES}

BEYRAMIZADE, Ebrahim; AZADI, Pejman and MII, Masahiro. Optimization of factors affecting organogenesis and somatic embryogenesis of Anthurium andreanum lind. Tera. Propagation of Ornamental Plants, December 2008, vol. 8, no. 4, p. 198-203.

CHAUDHRY, Bushra; YASMIN, Afshan; HUSNAIN, Tayyib and RIAZUDDIN, S. Mini-scale genomic DNA extraction from cotton. Plant Molecular Biology Reporter, September 1999, vol. 17 , no. 3 , p. 280. [CrossRef]

CHEN, Fure-Chyi and KUEHNLE, Adelheid R. Obtaining transgenic Anthurium through Agrobacterium-mediated transformation of etiolated internodes. Journal of the American Society for Horticultural Science, January 1996, vol. 121, no. 1, p. 47-51.

CHEN, Fure-Chyi; KUEHNLE, Adelheid R. and SUGII, Nellie. Anthurium roots for micropropagation and Agrobacterium tumefaciens-mediated gene transfer. Plant Cell, Tissue and Organ Culture, April 1997, vol. 49, no. 1, p. 71-74. [CrossRef]

DAI, Shunhong; ZHENG, Ping; MARMEY, Philippe; ZHANG, Shiping; TIAN, Wenzhong; CHEN Shouyi; BEACHY, Roger and FAUQUET, Claude. Comparative analysis of transgenic rice plants obtained by Agrobacterium-mediated transformation and particle bombardment. Molecular Breeding, January 2001, vol. 7, no. 1, p. 25-33. [CrossRef]

DUFOUR, L. and GUÉRIN, V. Growth, developmental features and flower production of Anthurium andreanum Lind. in tropical conditions. Scientia Horticulturae, March 2003, vol. 98, no. 1, p. 25-35. [CrossRef]

EL-SHEMY, Hany A.; TERAISHI, Masayoshi; KHALAFALLA, Mutasim M.; KATSUBE-TANAKA Tomoyuki; UTSUMI, Shigeru and ISHIMOTO, Masao. Isolation of soybean plants with stable transgene expression by visual selection based on green fluorescent protein. Molecular Breeding, September 2004, vol. 14, no 3, p. 227-238. [CrossRef]

FITCH, M.; LEONG, T. and ALBERT, H. Improvement in transformation of anthurium. In Vitro Cellular and Developmental Biology - Plants, June 2005, vol. 41, p. 30A.

FITCH, M.; LEONG, T. and ALBERT, H. Transformation of Anthurium with transgenes for bacterial blight and nematode resistance. In Vitro Cellular and Developmental Biology Plants, June 2006, vol. 42, p. 35A.

FRAME, Bronwyn R.; SHOU, Huixia; CHIKWAMBA, Rachel K.; ZHANG, Zhanyuan; XIANG, Chengbin; FONGER, Tina M.; PEGG, Sue Ellen K.; LI, Baochun; NETTLETON, Dan S.; $\mathrm{PEI}$, Dequing and KAN WANG, Kan. Agrobacterium tumefaciens-mediated transformation of maize embryos using a standard binaryvector system. Plant Physiology, May 2002, vol. 129, no. 1, p. 13-22. [CrossRef]

GODWIN, Ian; TODD, Gordon; FORD-LLOYD, Brian and NEWBURY, H. John. The effects of acetosyringone and $\mathrm{pH}$ on Agrobacterium-mediated transformation vary according to plant species. Plant Cell Reports, April 1991, vol. 9, no. 12, p. 671-675. [CrossRef]

JABEEN, Nyla; CHAUDHRY, Zubeda; RASHID, Hamid and MIRZA, Bushra. Effect of genotype and explant type on in vitro shoot regeneration of tomato (Lycopersicon esculentum M.). Pakistan Journal of Botany, December 2005, vol. 37, no. 4, p. 899-903.

JOUBÈS, Jérôme; DE SHUTTER, Kristof; VERKEST, Aurine; INZÉ, Dirk and DE VEYLDER, Lieven. Conditional recombinase-mediated expression of genes in plant cell cultures. Plant Journal, March 2004, vol. 37, no. 6, p. 889-896. [CrossRef] 
KANT, P.; KANT, S.; JAIN, R.K. and CHAUDHURY, V.K. Agrobacterium-mediated high frequency transformation in dwarf recalcitrant rice cultivars. Biologia Plantarum, March 2007, vol. 51, no. 1, p. 61-68. [CrossRef]

KHAITHONG, T.; SIPES, B.S. and KUEHNLE, A.R. Development of transgenic anthurium expressing modified rice cysteine protease inhibitor. In: Society of Nematlogists $45^{\text {th }}$ Annual Meeting, Lihue, Hawaii, June 18-21, 2006. Journal of Nematology, June 2006, vol. 38 , no. 2, p. 276-277.

KHAITHONG, T.; SIPES, B.S. and KUEHNLE, A.R. Transgenic Anthurium andraeanum expressing modified rice cysteine protease inhibitor and resistance to Radopholus similis. In: Society of Nematologists $46^{\text {th }}$ Annual Meeting, San Diego, California, July 28-August 1 , 2007. Journal of Nematology, June 2007, vol. 39, no. 1, p. 99-100.

KONCZ, Csaba and SCHELL, Jeff. The promoter of the TL-DNA gene 5 controls the tissuespecific expression of chimeric genes carried by a novel type of Agrobacterium binary vector. Molecular and General Genetics, September 1986, vol. 204, no. 3, p. 383-396. [CrossRef]

KUEHNLE, Adelheid R.; CHEN, Fure-Chyi and SUGII, Nellie. Somatic embryogenesis and plant regeneration in Anthurium andraeanum hybrids. Plant Cell Reports, August 1992, vol. 11, no. 9, p. 438-442. [CrossRef]

KUVSHINOV, V.; KOIVU, K.; KANERVA, A. and PEHU, E. Agrobacterium tumefaciens-mediated transformation of greenhouse Brassica rapa ssp. oleifera. Plant Cell Reports, May 1999, vol. 18, no. 9, p. 773-777. [CrossRef]

MIGUEL, C.M. and OLIVEIRA, M.M. Transgenic almond (Prunus dulcis Mill.) plants obtained by Agrobacterium-mediated transformation of leaf explants. Plant Cell Reports, January 1999, vol. 18, no. 5, p. 387-393. [CrossRef]

NUÑEZ-PALENIUS, Hector G.; FEBRES, Vicente J.; OCHOA-ALEJO, Neftalí; KLEE, Harry J. and CANTLIFFE, Daniel $\mathrm{J}$. Effect of explant source on regeneration and genetic transformation efficiency in galia melon (Cucumis melo L.) male and female parental lines. Agrociencia, 2007, vol. 41, no. 8, p. 853-861.

OLHOFT, Paula M.; FLAGEL, Lex E.; DONOVAN, Christopher M. and SOMERS, David A. Efficient soybean transformation using hygromycin B selection in the cotyledonary-node method. Planta, March 2003, vol. 216, no. 5, p. 723-735. [CrossRef]

PASZKOWSKI, Jerzy and WHITHAM, Steven A. Gene silencing and DNA methylation processes. Current Opinion in Plant Biology, April 2001, vol. 4, no. 2, p. 123-129. [CrossRef]

SAMBROOK, Joseph and RUSSELL, David W. Molecular Cloning. A Laboratory Manual. (3 $3^{\text {rd }}$ edition). New York, ColdSpring Harbor Laboratory Press, 2001. 2344 p. ISBN 0-87969577-3.

SHOU, Huixia; FRAME, Bronwyn R.; WHITHAM, Steven A. and WANG, Kan. Assessment of transgenic maize events produced by particle bombardment or Agrobacterium-mediated transformation. Molecular Breeding, February 2004, vol. 13, no. 2, p. 201-208. [CrossRef]

STACHEL, Scott E.; TIMMERMAN, Benedikt and ZAMBRYSKI, Patricia. Generation of singlestranded T-DNA molecules during the initial stages of T-DNA transfer from Agrobacterium tumefaciens to plant cells. Nature, August 1986, vol. 322, no. 6081, p. 706-712. [CrossRef]

STEWART, Jr C. Neal. Monitoring the presence and expression of transgenes in living plants. Trends in Plant Science, August 2005, vol. 10, no. 8, p. 390-396. [CrossRef]

VARGAS, Teresa E.; MEJIAS, Alexander; OROPEZA, Maria and GARCIA, Eva de. Plant regeneration of Anthurium andreanum cv Rubrun. Electronic Journal of Biotechnology, December 2004, vol. 7, no. 3. [CrossRef]

XU, Jin; WANG, Yu Zhen; YIN, Heng Xia and LIU, Xiao Jin. Efficient Agrobacterium tumefaciens-mediated transformation of Malus zumi (Matsumura) Rehd using leaf explant regeneration system. Electronic Journal of Biotechnology, January 2009, vol. 12, no. 1. [CrossRef]

YAO, Zhen; JI, Jin; WANG, Ping and WANG, Gang. Induction of callus and plantlet regeneration of Anthurium andraeanum. Journal of Jilin Agricultural University, February 2006, vol. 28, no. 1 , p. 43-46.

YILDIZ, Mustafa; ÖZCAN, S. and ER, Celâl. The effect of different explant sources on adventitious shoot regeneration in flax (Linum usitatissimum L.). Turkish Journal of Biology, February 2002, vol. 26, no. 1, p. 37-40. 
Zhao et al.

YU, Yi Xun; LIU, Ling; LIU, Juan-Xu and WANG, Jing. Plant regeneration by callus-mediated protocorm-like body induction of Anthurium andraeanum hort. Agricultural Sciences in China, May 2009, vol. 8, no. 5, p. 572-577. [CrossRef]

\section{How to cite this article:}

ZHAO, Q.; JING, J.; WANG, G.; WANG J.H.; FENG, Y.Y.; XING, H.W. and GUAN, C.F.. Optimization in Agrobacterium-mediated transformation of Anthurium andraeanum using GFP as a reporter. Electronic Journal of Biotechnology, September 2010, vol. 13, no. 5. http://dx.doi.org/10.2225/vol13-issue5-fulltext-2

Note: Electronic Journal of Biotechnology is not responsible if on-line references cited on manuscripts are not available any more after the date of publication. Supported by UNESCO / MIRCEN network. 